\title{
EDUCAÇÃO E SUBJETIVIDADE NA FORMAÇÃO DE VALORES \\ COOPERATIVOS: UMA PROPOSIÇÃO DE MÉTODO QUALI- QUANTITATIVO PARA AVALIAR FORMAÇÃO DE SUJEITOS COLETIVOS ${ }^{1}$
}

\author{
EDUCATION AND SUBJECTIVITY COOPERATIVE IN SECURITIES \\ TRAINING: A PROPOSAL OF QUALI-QUANTITATIVE METHOD FOR \\ ASSESSING SUBJECTS OF COLLECTIVE TRAINING
}

Vicente de Paulo Borges Virgolino da Silva²

RESUMO: Este artigo objetivou analisar de que forma e que valores cooperativos estão sendo construídos na Licenciatura em Educação do Campo da Universidade de Brasília, na prática docente e discente nos seus diferentes tempos educativos. Buscou ainda entender e aprofundar nas perspectivas teóricas, significados e sentidos da cooperação. Para atingir os objetivos usamos análises de conteúdos em entrevistas semi-estruturadas, no sentido de aferir a construção e agregação de valores cooperativos e níveis de consciência dos atores que participam do processo formativo da LEdoC. A abordagem é quali-quantitativa mensurando a agregação de valores vinculados aos níveis de consciência política. A média entre os segmentos estudados traduz em um nível de consciência política populista, onde podemos deduzir uma caracterização e uma relação de tutelamento entre os dois segmentos. Neste sentido podemos intuir que ainda existe um caminho a percorrer para atingirmos uma educação autônoma, libertária e que cumpra os pressupostos da LEdoC.

PALAVRAS-CHAVE: Educação do Campo. Licenciatura em Educação do Campo, Valores Cooperativos, Níveis de Consciência Política, Análise de Conteúdo.

ABSTRACT: This article aims to analyze how and cooperative values are being built in the Degree in Education Field at the University of Brasilia, in teaching and student practice in their different educational times. He has also sought to understand and deepen the theoretical perspectives, meanings and direc-

\footnotetext{
${ }^{1}$ Artigo baseado na tese apresentada ao Programa de Pós-Graduação em Educação da Faculdade de Educação da Universidade de Brasília/UnB. Área de Concentração em Educação e Ecologia Humana / Linha de Pesquisa em Ecologia Humana e Práxis Pedagógica / Eixo de Interesse em Educação do Campo, tendo como Orientadora a Profa Dra Mônica Castagna Molina.

${ }^{2}$ Doutor em Educação / Professor do Instituto Federal de Brasília. Planaltina - DF / Brasil / vicente.silva@ ifb.edu.br
}

Rev. Fac. Educ. (Univ. do Estado de Mato Grosso), Vol. 28, Ano 15, № 2 p. 149-179, jul./dez. 2017 
tions of cooperation. To achieve the objectives we use content analysis in semi-structured interviews, in order to assess the construction and aggregation of cooperative values and levels of awareness of the actors participating in the training process of LEdoC. The approach is qualitative and quantitative measuring the aggregation of amounts related to levels of political consciousness. The average between the segments studied translates into a level of populist political consciousness where we can deduce a characterization and a tutelamento relationship between the two segments. In this sense we can intuit that there is still a way to go to achieve an autonomous education, libertarian and satisfies the assumptions of LEdoC.

KEYWORDS: Countryside Education, Graduation in Countryside Education, Cooperative Values. Politic Consciousness Level, Content Analysis.

\section{Introdução}

Argumentamos que o processo educativo hegemônico do modelo capitalista, formador de consciência política intencional e não neutra, e que tem na escola um eficiente aparelho ideológico estrutural e supra-estrutural do Estado, reproduz a hierarquia, a individualidade, a competitividade, e a cultura da não participação na construção do conhecimento, alienando o sujeito da sua própria história.

O desenvolvimento sustentável e solidário que buscamos se dá na medida de superação dessa formação individualista, uma formação para a responsabilidade própria dentro de um contexto social concreto. Uma práxis educativa em evolução.

A Educação do Campo, nossa experiência analítica aplicada neste trabalho, surge como uma categoria política de educação em um ambiente de disputa de classe e da idéia de sujeitos coletivos de direitos, bem aportados por Molina e Arroyo, onde:

[...] Temos que defender o direito à educação como direito universal, mas como direito concreto, histórico, datado, situado num lugar, numa forma de produção, neste caso da produção familiar, da produção agrícola do campo; seus sujeitos têm trajetórias humanas, de classe, de gênero, de etnia, de raça, em que vão se construindo como mulheres, indígenas, negros e negras, como trabalhadores, produtores do campo [...] Os movimentos 
sociais nomeiam os sujeitos de direitos. Esses sujeitos têm rosto, têm gênero, têm classe, têm identidade, têm trajetórias de exploração, de opressão. Os movimentos sociais têm cumprido uma função histórica no avanço dos direitos, com seus rostos de camponês, trabalhador, mulher, criança. Sujeitos coletivos concretos, históricos (ARROYO, 2006 apud MOLINA, 2008, p. 28).

Em considerando a Licenciatura em Educação do Campo (LEdoC) da Universidade de Brasília (UnB), procuramos investigar a alternância como possibilidade viável de atender os sujeitos do campo em favor do antiautoritarismo, elegendo a Concepção Dialética ou Tendência Progressista Libertadora, valorizando o aluno, suas características vitais, correlacionando indivíduo, sociedade e escola, e priorizando o cotidiano das pessoas. Ainda, de forma dialética, escolher parâmetros relacionados à vivência, transformando as comunidades a partir de sua práxis.

\section{Do Direito Coletivo à Educação}

Segundo Sá (2009), desde o início da década de 2000, a partir das lutas dos movimentos sociais do campo e da sociedade civil organizada, surgem novas possibilidades organizativas demandando novas políticas públicas. Já Santos (2009) classifica em três grandes ciclos as lutas por direitos sociais dos movimentos do campo, onde surge no primeiro momento o direito à educação vinculada ao movimento por reforma agrária, num segundo momento observase avanços nas políticas públicas e nas conquistas dos movimentos sociais do campo, e o terceiro ciclo, que se caracteriza pela tentativa de criminalização dos movimentos sociais, desconsiderando e desqualificando os sujeitos do campo como sujeitos de direitos.

Os movimentos reais de controle e o atendimento a novas demandas de necessidades sociais propiciam surgimento de novas percepções, que por sua vez faz emergir novos conhecimentos que naturalmente mostram-se contrários a um status quo, gerando, portanto, conflitos que, segundo Coser (1961), é uma categoria central e parte fundamental e constitutivo da organização social, onde o processo social é uma incessante reação de pessoas movidas por interesses que se ordenam em conjuntos cooperativos, os quais nestes se incluem elementos de conflito, que podem por sua vez entrar em conflito com outros conjuntos, onde dessa oposição aberta se eliminam os protestos, e, por parte do elemento dominante, gera-se uma sociedade vigorosa e hegemônica. 
No caso particular dos camponeses, busca-se um diálogo com teorias pedagógicas clamando por um modelo de educação do campo que atenda uma particularidade desses sujeitos concretos, que apesar de necessitar da dimensão universal da educação, apresentam determinadas condições sociais específicas caracterizadas pela pobreza, degradação da qualidade de vida, desigualdade social e exclusão, fruto da implantação do modelo capitalista de produção no campo (MOLINA, 2008).

Essa autora concordando com o contexto conflituoso, contraditório e complexo, aponta fatores como globalização econômica, inovações tecnológicas e novos modos de organização do trabalho, como mudanças estratégicas de acumulação de capitais e manutenção de uma ideologia hegemônica, influenciando diretamente em políticas sociais e, entre elas, a educação, restringindo o âmbito de atuação do Estado e consolidando um modelo societário desigual e injusto. Portanto torna-se necessário adotar planos e métodos de educação colaborativos e que promovam valores sociais mais justos.

As formações humanizadas, multidimensionais, dialéticas e dialógicas, estão presentes na proposta da Educação do Campo, em contraposição à educação escolar que vem sendo determinada na grande maioria das instituições de ensino do Estado, a partir de ideários culturais e econômicos dominantes.

A formação de consciência política e a formação do sujeito coletivo são contempladas como condição para movimentos cooperativos neste trabaIho, por entender que estes se ancoram em identidades coletivas a partir das subjetividades dos sujeitos, interesses e necessidades comuns.

\section{Relações entre consciência política e movimentos cooperativos}

Buscamos neste trabalho melhor compreender como indivíduos se inserem em seus grupos sociais, em uma perspectiva intencional de um processo educativo que não se limita a feitos individuais.

No nosso caso enfocamos como se deram as interferências da LEdoC, investigando vivências individuais de discentes, dotados subjetivamente de marcas culturais e estado psico-sociológico de consciência política, à luz de experiências coletivas frente a movimentos sociais.

Outra proposição que fundamenta princípios desse trabalho, concordando com o sentido prenunciado por Reck (2005), é que o principal promotor de movimentos cooperativos, a partir do indivíduo, se dá na formação do sujeito coletivo à medida que se amplia a percepção da formação de consciência política de pertencimento dos sujeitos a grupos sociais. A análise se dá de forma 
crítica, reflexiva e contextual, onde

a identidade coletiva, a solidariedade de um grupo e o comprometimento político são continuamente forjados - moldados, destruídos e remodelados - em consequência de conflitos no decorrer dos quais partidos políticos, escolas, sindicatos, igrejas, jornais, exércitos e empresas procuram impor às massas uma determinada visão de sociedade [...] O comportamento político dos indivíduos somente pode ser compreendido na articulação histórica concreta com esses conflitos, pois as características específicas tornam-se causas de atos individuais quando estão inseridas em uma estrutura definida, imposta às relações políticas em um dado momento da história (PRZEWORSKI, 1989, p. 118).

Como acima mencionado, deve-se ter clara noção de que estrutura se está investigando, pois segundo Sandoval (1994, p. 60-62), escolher parâmetros de análise diferencia a percepção de como se condicionam e moldam as relações de classe e que vem afetar a consciência política; citando divisão social do trabalho, relações de autoridade e poder do sistema político e produtivo, bem como influência de padrões culturais e de consumo. Tendo o sujeito como produto de relações sociais, absorvendo e processando culturas, construindo pensamento e linguagens que refletem a realidade de forma diferente conforme percepções subjetivas, possibilitando diferenciar a natureza e níveis de consciência. Conforme Vigotsky (1993), a palavra surge como o microcosmo da consciência humana.

A não participação política ou isenção nas tomadas de decisões, seja por comodismo ou medo da responsabilidade, revela a inconsciência e o grau de alienação da pessoa. Essa retomada de consciência passa pelo processo de educação, de forma solidária e democrática, com a participação de intelectuais, não necessária, mas preferencialmente orgânicos, com pertencimentos aos contextos e ideologias conceituais e filosóficas, auxiliando na elaboração da organização de um grupo social (GRAMSCl, 1982).

É na formação da consciência política e participativa, a partir do indivíduo, na formação do sujeito coletivo, que se formam novos grupos com diferentes percepções da realidade e capazes de transformações baseadas em ações-reflexões coletivas e solidárias.

A categoria que une educação e cooperação é o trabalho (referencia marxista de humanização e aprendizagem). A pedagogia da Práxis surge a partir de necessidades concretas, os seres humanos vivenciam trabalho cooperativo e educação. 


\section{Sentidos de Cooperação - A Perspectiva Teórica de Cooperação}

As "teorias da cooperação" nos baseiam diversos movimentos de organização social na história da humanidade. Contempla todas as dimensões da vida humana, tendo o cooperativismo se caracterizado pela sua inserção na economia, priorizando essa dimensão e se adaptando aos diversos modos de produção e regimes de governos.

Se ampliando e superando o sentido de estrutura organizacional ou empresa, a cooperação surge como fenômeno de ajuda mútua, presente nos diversos povos e em todas as épocas (ANDRIOLI, 2007, p. 33-35).

Essa relação entre humanos se apresenta como uma ação consciente de sua incapacidade de resolver problemas individualmente, construindo a partir dessa percepção relações de sociabilidade e de trabalho (idem, p. 35).

Na contramão da tendência de exploração dos homens pelos homens, Andrioli (2007, p. 37) aponta que "é a partir da forma de organização que podemos contribuir para modificar as estruturas de dominação da sociedade, construindo novas relações entre as pessoas".

Além do caráter organizativo a ação cooperada ainda se apresenta como potencial educativo e que propicia uma democracia participativa. Nesse sentido, Andrioli (idem) citando Marx (1973), reconhece o movimento cooperativo como força transformadora da sociedade atual, onde o sistema de subordinação do trabalho ao capital pode ser suplantado pelo sistema republicano da associação de produtores livres e iguais.

Neste trabalho desenvolvemos intencionalmente uma estreita ligação entre educação, formação de valores cooperativos e formação de consciência política. Essa indissocialidade encontra apoio em Andrioli quando esse anuncia que

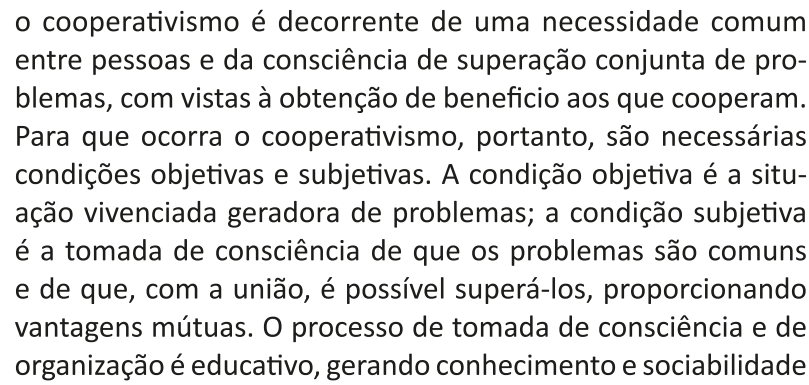


(ANDRIOLI, 2007, p. 40).

Assim como o trabalho, a educação surge como o processo de humanização, se diferenciando deste na medida em que se questiona sobre a finalidade do que é humano e construindo consciências que possam, livremente, optar e se responsabilizar pelas suas ações.

Neste aspecto Andrioli (2007, p. 42) afirma que “a educação está fundada no meio social onde ela atua e por isso não é neutra: pode atuar como promotora do meio ou contribuir para a sua superação".

Da mesma forma, a educação pode reproduzir ou transformar relações de poder ou novas formas de sociabilidade, validando ou modelando estruturas sociais, a partir da geração de consciências e formação da cultura humana.

Concordando com os autores Maturana (1999) e Andrioli (2007, p. 43), podemos afirmar que a cooperação, assim como a educação, está na raiz da sociabilidade, são frutos da prática social, da cultura humana. Como tal não possuem um local de início definido e permanecem inacabadas, assim como a própria história humana.

Andrioli sintetiza bem a relação intrínseca entre a consciência do humano quanto ao inacabamento de suas construções sociais e da sua capacidade de aprender, condições para uma educação que defronte os problemas concretos vivenciados pelos humanos e que seja capaz de desvelar soluções a partir de seus coletivos. Onde aponta que

[...] a aprendizagem é um processo cooperativo e a cooperação volta a ser um permanente processo de aprendizagem: a prática social da convivência humana. O cooperativismo carece do espaço educativo para se reproduzir e a educação, baseada na convivência, decorre das relações cooperativas das pessoas (ANDRIOLI, 2007, p. 44-45).

Andrioli (2007, p. 201-208) aponta conclusões essenciais para as nossas discussões. A primeira mostra que a maior importância das experiências cooperativas nas escolas, bem como organizações coletivas, é a formação de consciência da importância da cooperação. A segunda se refere a práticas de organização escolar e social como resultado de trabalho coletivo fazendo emergir e potencializando críticas e contradições da realidade vivenciada. A terceira diz respeito a possibilidade da convivência desenvolver novas relações sociais, contribuindo com a construção de consciência de grupo. A última traz a importância da vivência de conceitos de cooperação resultando em mudanças no comportamento dos alunos, com destaque à participação, organização e 
responsabilidade em grupo.

A conscientização e a mobilização coletiva são a resistência e a mudança da condição de coisas-pessoas para o protagonismo da recuperação da liberdade e do sentido do poder em benefício da maioria. É na formação da consciência política e participativa, a partir do indivíduo, na formação do sujeito coletivo, que se formam novos grupos com diferentes percepções da realidade e capazes de transformações baseadas em ações-reflexões coletivas e solidárias. Nossa análise se dará no processo formativo da segunda turma da UnB em Licenciatura em Educação do Campo, em especial com os professores que atuaram em disciplinas que foram veiculadas até o terceiro semestre (2009/2010), com seus respectivos conteúdos, e o grupo de nove alunos do assentamento Itaúna.

\section{Categorias de Cooperação Segundo Jair Reck e Salvador Sandoval - Formação de Consciência Política}

Como ponto de partida, adotaremos para a compreensão da construção da consciência política o modelo desenvolvido pelo professor Salvador Sandoval ${ }^{3}$ (2001, p. 186), já comprovadamente eficiente na aplicação de trabaIhos dessa natureza, como no caso da Tese de Doutorado de Jair Reck (2005), anteriormente citada, composta por sete categorias para compreender as formas de ação individual ou coletiva, quais sejam: Identidade Coletiva; Crenças e Valores Societais; Identificação de Adversários e de Sentimentos Antagônicos; Sentimentos de Eficácia Política; Sentimentos de Justiça e Injustiça; Vontade de Agir Coletivamente e, por fim, as Metas de Ação Coletiva.

É consenso desse trabalho com o que afirmam Salvador Sandoval e Jair Reck, para quem o estudo da consciência política e de sua formação, não se desvincula das ações coletivas, dos valores e visões societais, das alternativas comportamentais possíveis e implícitas em situações específicas de relações de poder. Bem como a abordagem psico-sociológica da participação das pessoas frente às ações coletivas e os movimentos sociais.

\footnotetext{
${ }^{3}$ O modelo geral da consciência política de Sandoval (2001) foi aplicado com sucesso para a compreensão da queda da atividade grevista no Brasil na década de 1990 (SANDOVAL, 2001); da constituição do MST (SILVA, 2002); na compreensão da resistência de trabalhadores a processos de privatização (PALASSI, 2004), à consciência política de conteúdo ambiental de comunidades afetadas por contaminações (CALDERONI, 2004) e na compreensão das formas de consciência política dos cooperados do MST, o caso da CoopacCampo Verde- MT (RECK, 2005).
}

Rev. Fac. Educ. (Univ. do Estado de Mato Grosso), Vol. 28, Ano 15, № 2 p. 149-179, jul./dez. 2017 
Os Sentidos de Cooperação entre Camponeses (as) Participantes de Movimentos Sociais do Campo no Brasil - Laudemir e Gitahy

Laudemir Luiz Zart, professor em Sociologia Política da UNEMAT e, Leda Gitahy, professora de Política Científica e Tecnológica da UNICAMP, em trabalho encaminhado para a V Jornada de Investigação em Antropologia Social da Universidade de Buenos Aires (2008), produto de experiência acadêmica no curso de Agronomia dos Movimentos Sociais do Campo (CAMOSC-MT), contribuíram na detecção do sentido de cooperação no âmbito dos Movimentos Sociais e de Camponeses da Reforma Agrária, com experiências em formas coletivas de educação e produção, utilizando para isto entrevistas abertas em profundidade entre camponeses de RO-MG-DF-PR-MS-MT, legítimos representantes de camponeses brasileiros.

Suas concepções de cooperação apresentam categorias expressa pelos camponeses a partir de ações entre sujeitos, mediados por organizações, com finalidade da coletividade ou mobilizadora; expressa por entidades promovedoras dos processos cooperativos tendo associações, cooperativas e grupos coletivos atuando em dimensões políticas, econômicas e comunitárias; bem como nas práticas dos camponeses em relação aos processos de cooperaçãomostrando suas limitações explicadas por Dimensões Sócio-Educativas, Sentido Político e Cultural da compreensão de coletividadee Dimensão Educacional-Formativo.

Esses sentidos expressam as subjetividades, as vontades e os sonhos dos sujeitos sociais. Dependem de construções Socioculturais (limitados pelo individualismo, oportunismo, desmotivação, desconfiança, com contradições de ajuda, alteridade e complementaridade), Socioeducativos (formação de consciência política e social), Histórico-estruturais (infra-estruturas e organizações com viés de uma sociedade mais solidária e democrática), e Ideopolíticas (os camponeses desejam práticas coletivas de cooperação), com referenciais teóricos e práticos na formação de valores.

Acreditamos que o caminho sempre a ser buscado é o da participação, da mutualidade, da dialogicidade, da complementaridade, da coletividade e da solidariedade. 


\section{Proposição Metodológica}

Este trabalho, como princípio, adota a subjetividade no processo formativo de pessoas em um determinado espaço e tempo, e portanto adequadamente enquadrado como Método de Estudo de Caso com abordagem qualitativa, com percepções de que o pesquisador contamina o objeto investigado de acordo com suas habilidades necessárias para investigações científicas, não inerentes apenas ao Método de Estudo de Caso (YIN, 2001).

$A$ intencionalidade do uso desse método é justamente o aspecto mais interessante de sua natureza, que conforme Stake (In DENZIN; LINCOLN, 2001), sua epistemologia harmoniza com a experiência daqueles que com ele estão envolvidos, fundamentados na relação entre a profundidade e tipo de experiência vivida, a expressão dessa experiência e a compreensão da mesma. As análises dos resultados devem prestigiar princípios éticos, quanto a possíveis generalizações, tendo na construção do conhecimento, muitas vezes, a reflexão e a compreensão de um movimento tácito e em consonância com a vida real.

A ferramenta analítica escolhida para este estudo de caso é a análise de conteúdo por considerar e reconhecer a Psicologia, e mais especificamente a Psicologia da Educação, uma ciência autônoma que tem no poder da "fala" humana, na sua expressão verbal, seus enunciados e suas mensagens, manifestações do comportamento humano, indicadores indispensáveis para a compreensão dos problemas ligados às práticas educativas e a seus componentes psico-sociais (FRANCO, 2007). Reconhece o papel ativo do sujeito na produção do conhecimento e sua mensagem passa a ser ponto de partida, seja ela verbal (oral ou escrita), gestual, silenciosa, figurativa, documental ou diretamente provocada, para representar elaborações mentais das representações sociais.

O significado das mensagens dependerá de categorias definidas a partir das discussões dos diferentes autores sobre valores cooperativos e formação do sujeito político, já o sentido terá um significado pessoal concretizado na prática social a partir de representações sociais, cognitivas, subjetivas, valorativas e emocionais, necessariamente contextualizadas.

\section{Categorias de Análise ou de Conteúdo - Unidades de Registro e Unidades de Contexto}

As unidades de registro são a menor parte do conteúdo, e sua ocorrência é registrada de acordo com as categorias levantadas. Cada uma dessas 
unidades deve ter significado, que são características definidoras (corpus de significação) e sentido, significado pessoal e objetivado concretizado na prática social, cognitiva, subjetiva, valorativa e emocional, necessariamente contextualizadas (FRANCO, 2007, p. 41-47).

A característica desse trabalho nos induz escolher o tema como unidade de registro, pelo fato de que, certamente, ocorrerá um grande número de respostas permeadas por diferentes significados (FRANCO, 2007, p. 43). Principalmente, pela a interpretação ter de considerar que as respostas se darão a partir de grupos de pessoas, de contextos e formação diferentes, grupo de alunos e de professores. Deverão ser realizadas análises e interpretações dos conteúdos de cada resposta em seu sentido individual e único, para depois recodificá-la.

O tema se configura como mais útil unidade de registro, indispensável em estudos de representações sociais, opiniões, expectativas, valores, conceitos, atitudes e crenças. Seus limites não são facilmente identificáveis como assim na palavra, parágrafo ou item. Portanto, nossas unidades de registros serão classificadas como sendo unidades temáticas, por considerar que as categorias escolhidas apresentam um amplo espectro de significados e sentidos, não podendo se enquadrar na menor unidade de registro, a palavra.

Franco (2007, p. 47) caracteriza a unidade de contexto como a parte mais ampla do conteúdo a ser analisada. É indispensável para estabelecer as diferenças dos conceitos de significado e sentido. Pode-se dizer também que é o "pano de fundo" que imprime significado às unidades de análise. É presidida por dois critérios: custo e pertinência.

Deve ficar claro qual contexto a partir do qual as informações foram elaboradas, concretamente vivenciadas e transformadas em mensagens personalizadas, socialmente construídas e expressas via linguagem (oral, verbal ou simbólica), passiveis de transformações ou reconstruções (idem, 2007, p. 49).

A partir das aproximações entre as categorias da formação de consciência do sujeito político e os sentidos de cooperação dos camponeses, descrevemos no Quadro 1, as unidades de registro e de contexto. 
Quadro 1 - Aproximações entre as Categorias da Formação de Consciência do Sujeito Político e os Sentidos de Cooperação dos Camponeses

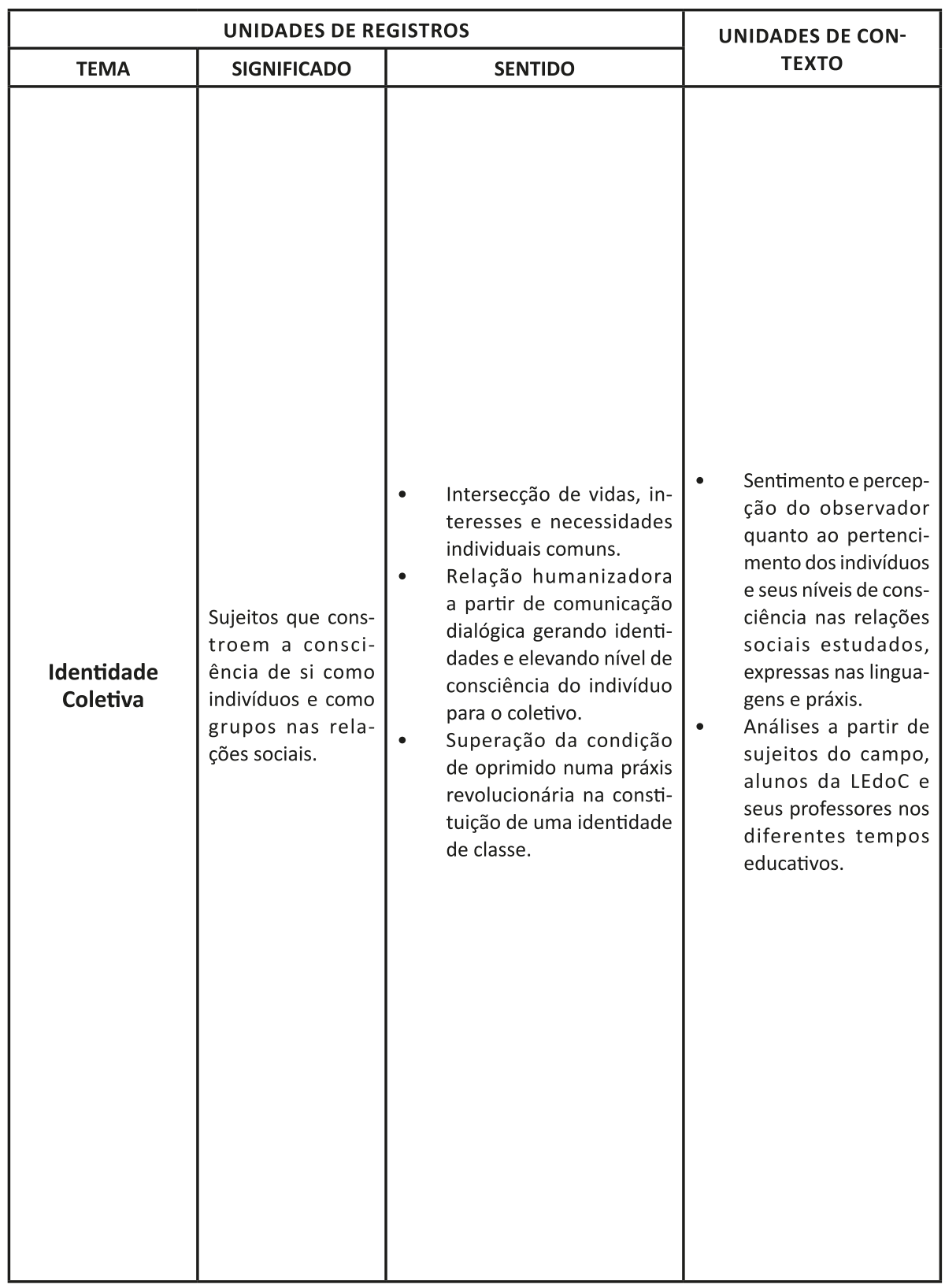

Rev. Fac. Educ. (Univ. do Estado de Mato Grosso), Vol. 28, Ano 15, № 2 p. 149-179, jul./dez. 2017 


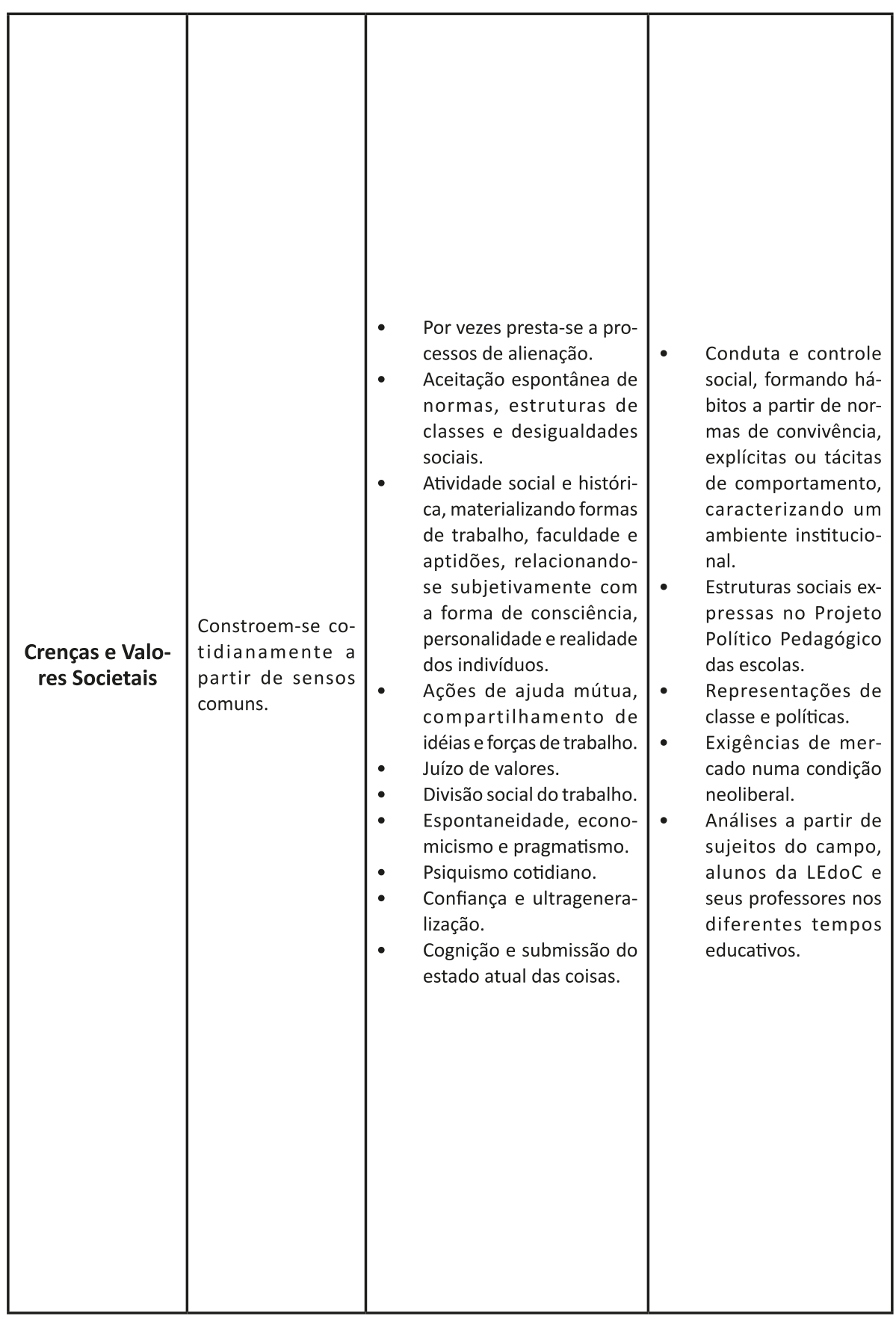


Identificação de adversários e sentimentos antagônicos
A partir de interesses, simbólicos e materiais, individuais e coletivos, ter consciência do movimento conflituoso e desigual do estado atual das coisas.
- $\quad$ Necessidade de participação na defesa de interesses.

- Visão de sujeitos coletivos de direitos e identificação de adversários.

- Conflito antagonista de atores na luta de recursos valorizados por ambos.

- Reconhecer e legitimar poder de grupos na gestão de recursos.

- Ideários conflituosos frente a modelos de desenvolvimento.

- Concentração de poder decisório.

- Individualismo caracterizando baixa formação política e de consciência.

- Comunicação de massa promovendo aculturamento.

- Competição e oportunismo.

- $\quad$ Experiências frustradas de ações cooperativas.

- $\quad$ Ausência de resultados no coletivo, desmotivação e desconfiança.

- Separação da economia e política.

- Neoliberalismo.
- $\quad$ Prática da LEdoC e sua proximidade com a materialidade de origem dos sujeitos e movimentos sociais do campo desvelando o caráter de poder e antagônico nas relações de classes (na medida em que ocorrem conflitos de interesses).

- $\quad$ Luta contra hegemônica do modelo capitalista de produção e reprodução social.

- Práticas educativas e estruturas de instituições de ensino frente às novas demandas dos sujeitos do campo.

- Análises a partir de sujeitos do campo, alunos da LEdoC e seus professores nos diferentes tempos educativos. 
Sentimentos de eficácia política
Parte do indivíduo frente a um fato social.
- Causa divina ou transcendental, causando imobilidade social.

- Auto-culpabilização demonstrando despolitização de consciências das verdadeiras causas.

- Visão crítica da realidade, com postura pró ativa percebendo o lócus do conflito nos outros indivíduos ou grupos, potencializando a eficácia de ações.

- $\quad$ Afirmação de cultura política gerando o espírito da conquista na mobilização.

- $\quad$ Aprender na convivência e disciplina na organização para conquistas.

- $\quad$ Organização que se amplia na práxis do movimento do diálogo entre divergências e ideias.

- Participação na constituição do grupo.

- $\quad$ Pouca formação política.

- Diversidade cultural limitando interações sociais.

- Meios de comunicação de massa uniformizando ideários baseados no individualismo, descrédito no coletivo, ausência de resultados.

- Baixo nível de consciência.

- Experiências frustradas.

- Priorização do econômico e financeiro.

- Desconfiança.
Situa-se os espaços diferentes em relação às causas dos fenômenos sociais e de como se apresenta o empoderamento do sujeito para modificar politicamente a realidade.

Análises a partir de sujeitos do campo, alunos da LEdoC e seus professores nos diferentes tempos educativos. 
Sentimentos de justiça e injustiça
Manifestação quando se constrói a consciência de ruptura de reciprocidade nas relações sociais, tanto em nível individual quanto numa perspectiva de classes.
- Ação reivindicativa de competição pública quanto à distribuição de recursos, regras sociais e divisão do trabalho.

- Sentimento de marginalização.

- Ampliação na participação de decisões contra o desequilíbrio do jogo político.

- Conflitos que atingem os modos de produção, seus objetivos sociais e políticos de desenvolvimento. Respeito das individualidades e da coletividade num processo de construção cultural, econômico e político.

- Relações comerciais oportunistas.

- Dominação do trabalho pelo capital.

- Problemas administrativos quando uns trabalham e outros não - consciência individual frente ao coletivo.
- Eventos que abalam o cotidiano.

- Pode desencadear atos de protestos ou lutas sociais.

- Análises a partir de sujeitos do campo, alunos da LEdoC e seus professores nos diferentes tempos educativos. 


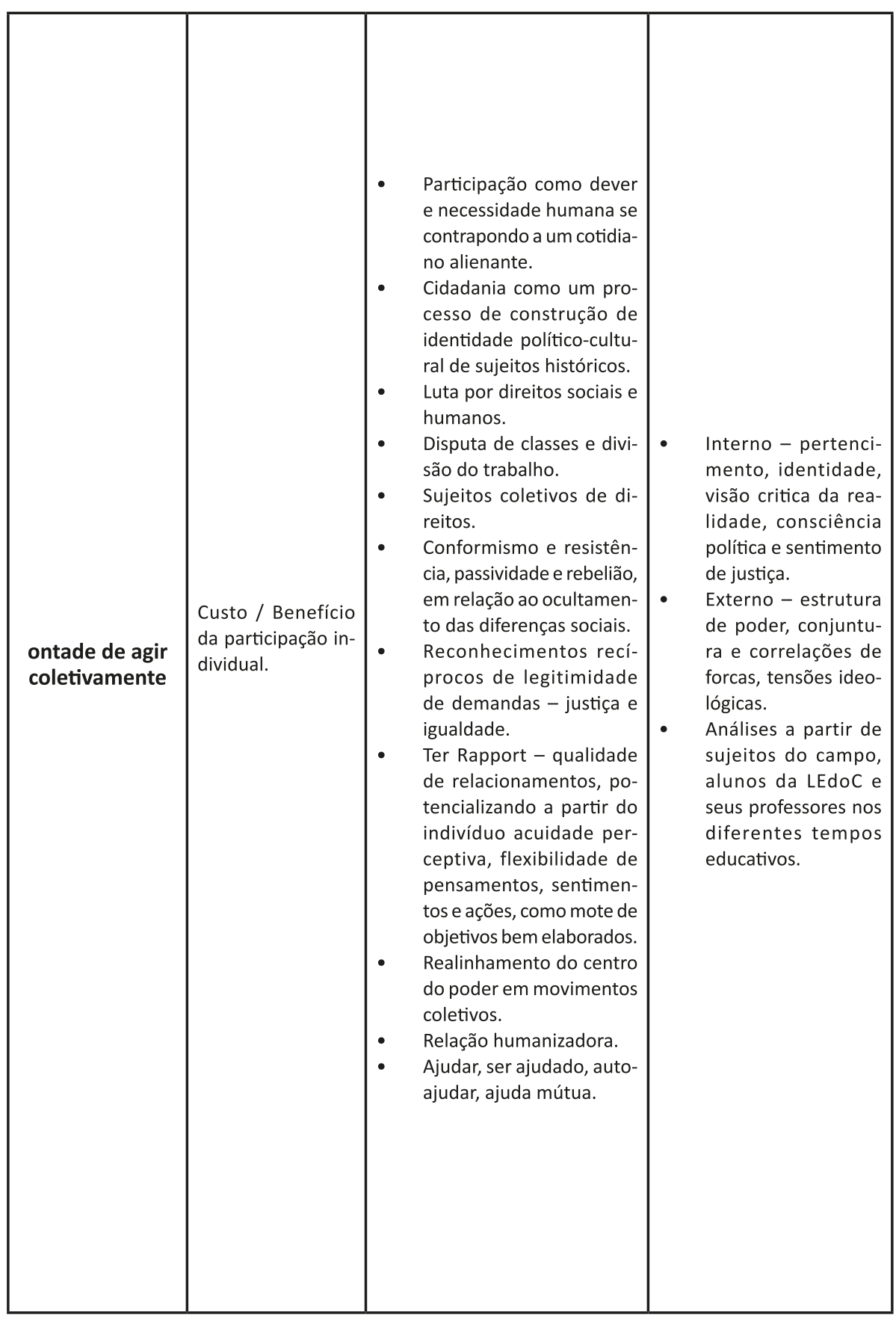




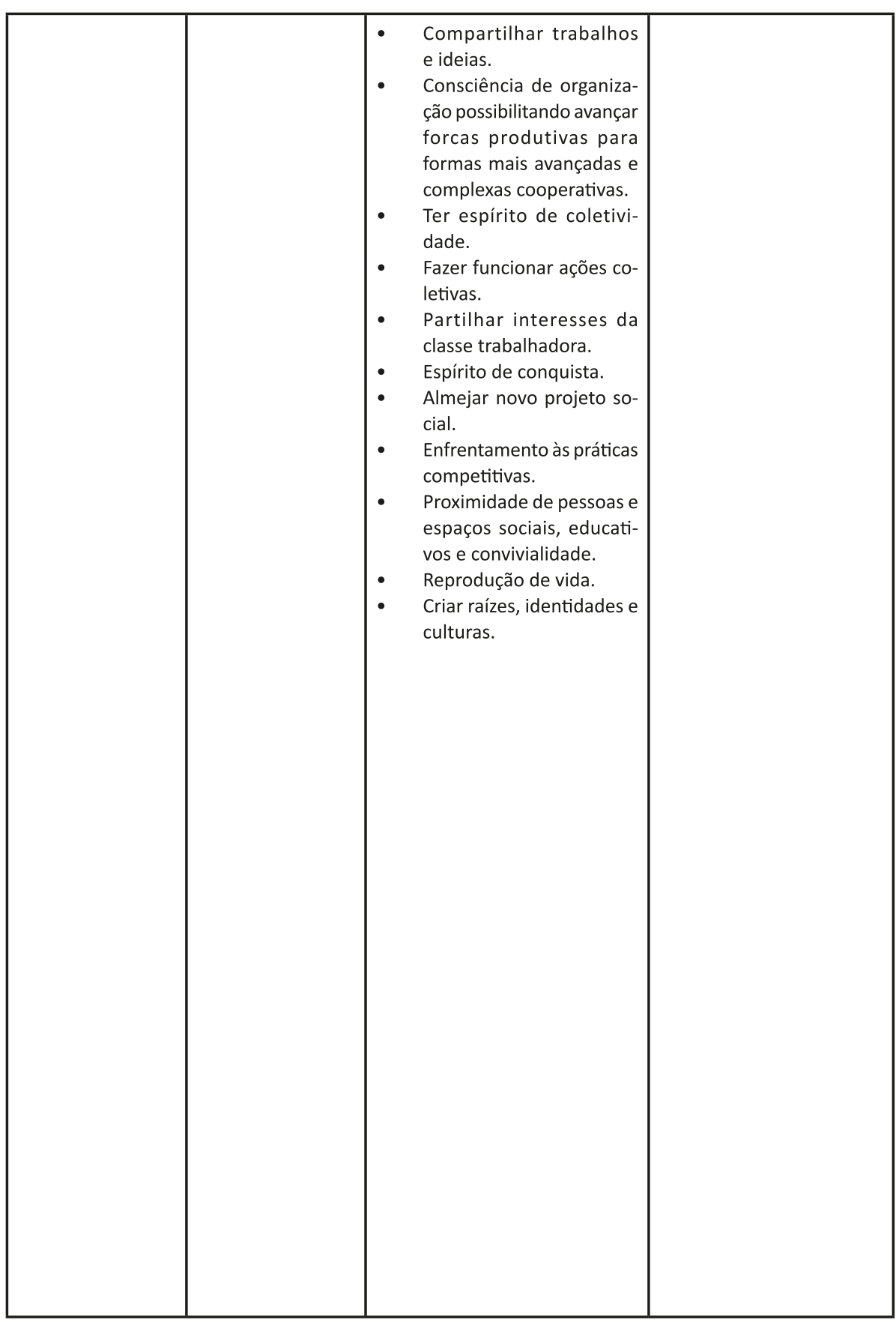

Rev. Fac. Educ. (Univ. do Estado de Mato Grosso), Vol. 28, Ano 15, № 2 p. 149-179, jul./dez. 2017 


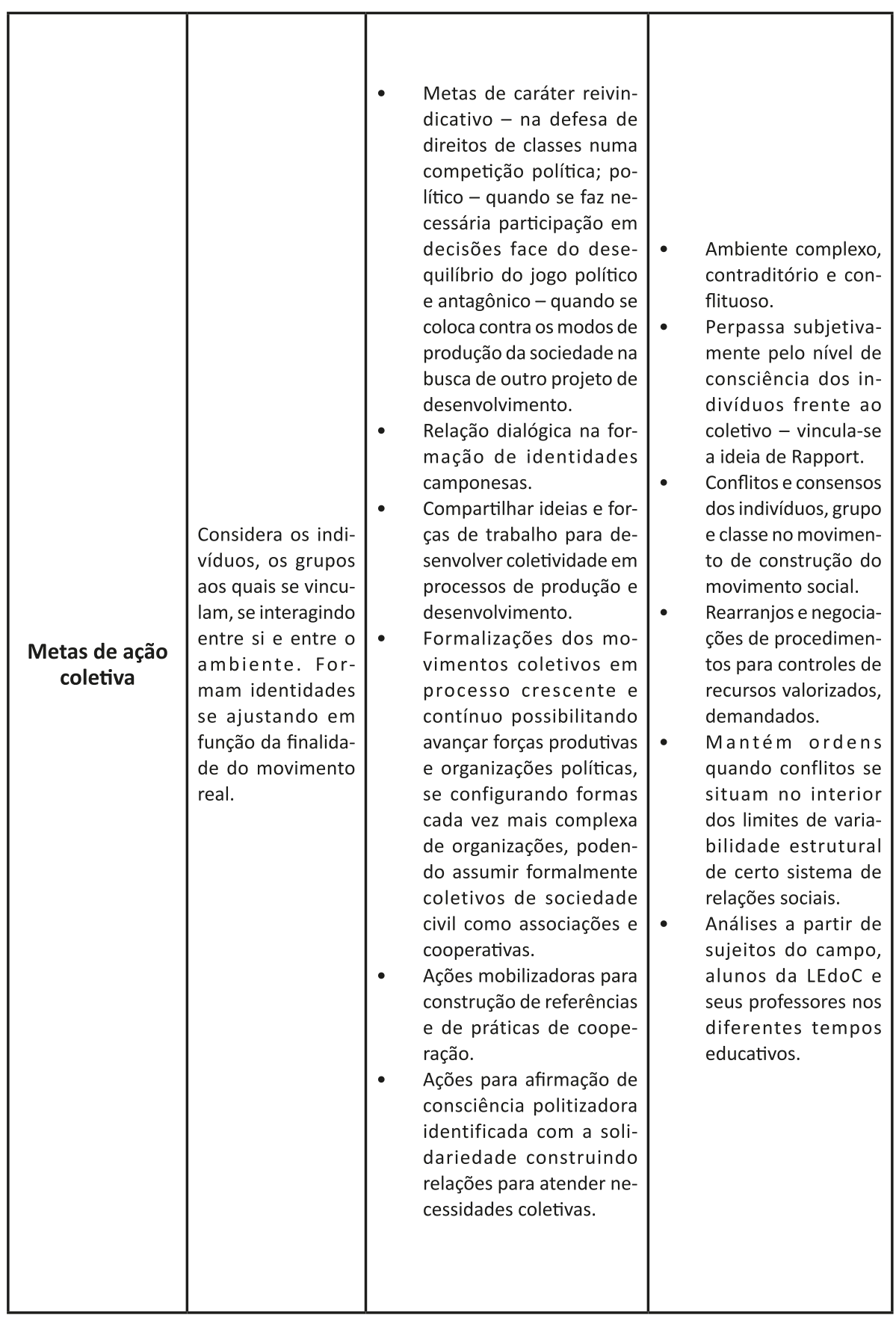

Rev. Fac. Educ. (Univ. do Estado de Mato Grosso), Vol. 28, Ano 15, № 2 p. 149-179, jul./dez. 2017 


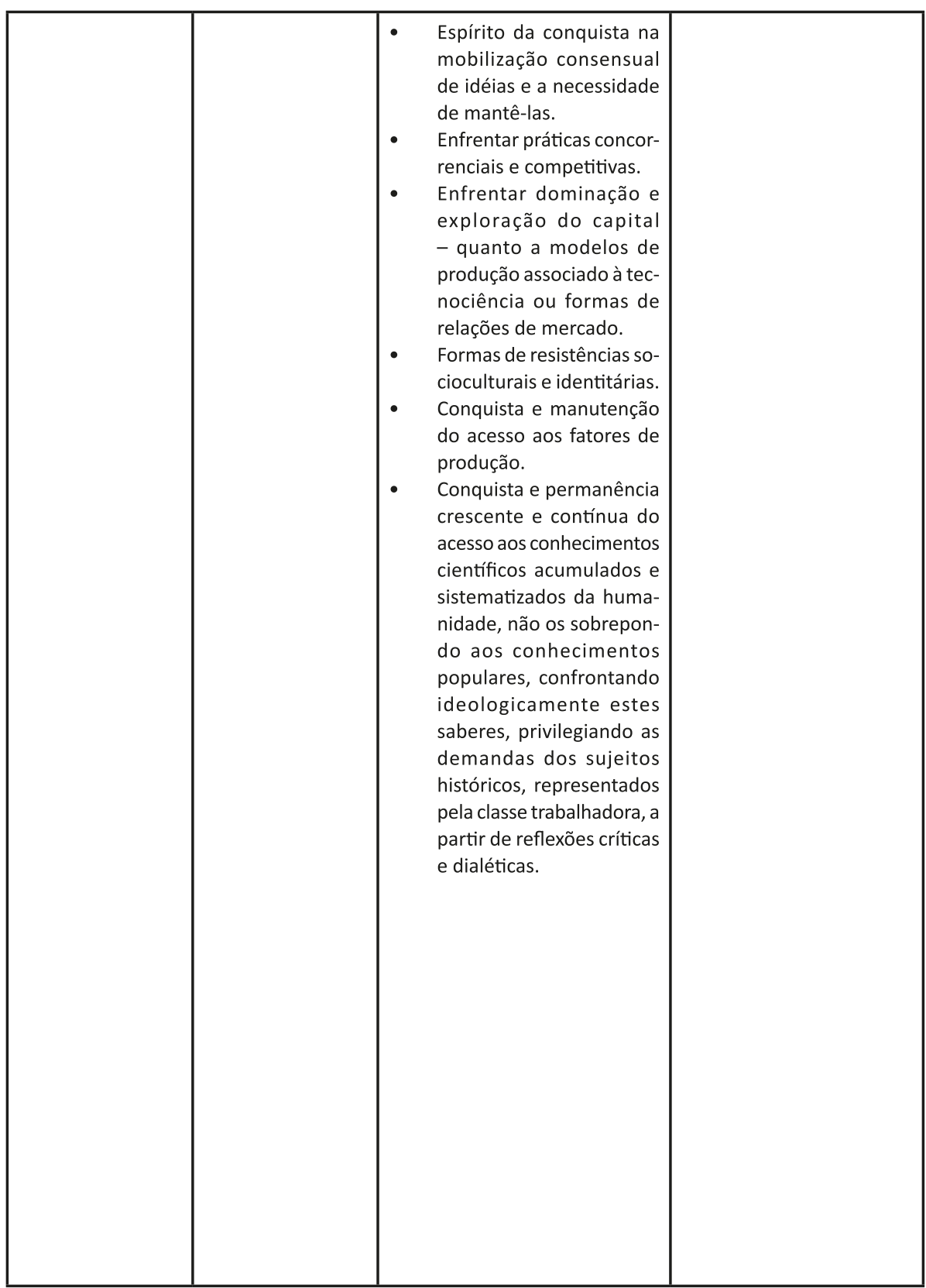

Fonte: Sintetizado pelo próprio autor baseado em Sandoval (2011), Reck (2005), Zart \& Gitahy (2008) 
A Unidade Temática Difusa (UTD) é utilizada para apontar uma dificuldade de enquadramento da ocorrência do fato analisado, visto principalmente a sua profundidade e complexidade, impactando na construção positiva ou negativa dos valores em todos os indicadores, em maior ou menor grau, influenciando na construção de consciência política do sujeito analisado.

$\mathrm{Na}$ tentativa de fazer uma síntese transversal frente às unidades de registros consideradas e descritas, é um principio desse trabalho a formação de consciência política e seu vínculo com ações coletivas, com valores e visões societais, com alternativas nas relações de poder, tendo na subjetividade da participação das pessoas quando confrontadas às ações coletivas e os movimentos sociais, uma abordagem psico-sociológica.

\section{Níveis de consciência}

Para permanecer fiel aos princípios e objetivos desse trabalho, optou-se em permanecer na linha da tese de Jair Reck (2005, p. 197), onde este utilizou a classificação de níveis de consciência na formação do sujeito político, citando dois autores Sandoval ${ }^{4}$ (1989) e Vázquez ${ }^{55}$ (1990). Para efeitos operacionais mesclamos as duas classificações e às quantificamos equitativa e acumuladamente, com intenção de didaticamente possibilitar apresentar os resultados das análises de conteúdos referentes aos níveis de consciência dos sujeitos nos seus processos formativos. Ficaremos a princípio com as seguintes delimitações: Consciência de senso comum $(0,5)$; Consciência populista $(1,0)$; Consciência da práxis/política, criadora, reflexiva $(1,5)$; Consciência revolucionária/crítica $(2,0)$.

Cada um desses limites se deu na medida em que os atores entrevistados externalizaram seu grau de consciência política, a partir da fala e/ou outras representações, onde a quantificação se fez utilizando uma escala de freqüência e de sentidos em relação à ocorrência das unidades de registros.

\footnotetext{
${ }^{4}$ A) Consciência de senso comum: cotidiano, escassas noções de direitos de cidadania; B) consciência populista = figuras políticas, clientelismo; C) consciência de conflito = mediação institucional, partido, sindicato, associação; D) consciência revolucionária/crítica = vê o conflito de classes antagônico, vê a necessidade de reorganização macroestrutural profunda do poder/ isto só se dá através de ações coletivas de classe. 0 adversário é definido a partir do interesse de classe, tanto local quanto globalmente.

${ }^{5} \mathrm{~A}$ ) consciência comum = imediato, ingênuo, imitativo ou reiterativo. B) consciência prática = busca transformar um resultado ideal em real; C) consciência da práxis/política, criadora, reflexiva = é a que se volta sobre si mesma, e sobre a atividade material em que se plasma. Pode-se dizer que a consciência da práxis vem a ser a autoconsciência prática. Persegue determinados objetivos que correspondam aos interesses radicais das classes sociais. Práxis política, enquanto atividade transformadora alcança sua forma mais alta na práxis revolucionária, como etapa superior da transformação prática da sociedade.
} 
Para diferenciar os graus de importância quanto aos sentidos das representações utilizaremos a escala de Likert.

\section{Escala de Likert}

Para avaliação da conformidade das unidades de registros na análise de conteúdo, propomos enquadrar os temas como sendo direcionadores e os sentidos como subfatores. Pois, de acordo com a subjetividade discricional e facultativa do analista, os registros podem se apresentar com atribuições de pesos diferenciados em função das suas importâncias. Nesta condição surge a Escala de Likert como uma boa ferramenta para avaliação do desempenho dos registros a partir dos conteúdos apresentados pelos sujeitos analisados. Cabe ressaltar que a presença das unidades de registros nem sempre significam que são favoráveis à formação da consciência política, alguns deles ocorrem enquanto limitantes dessa construção.

Para isso em Likert utiliza-se uma escala que varia de -2 a +2 , significando muito desfavorável para -2 , quando houver conformidade com um sentido limitante ao fortalecimento do subfator, a muito favorável +2, existindo conformidade favorável ao subfator. Os valores intermediários $-1,0$ e +1 , correspondem à desfavorável, neutro e favorável, respectivamente (SILVA, 2005 , p. 70). Temos uma concepção neste trabalho que em posições políticas, mesmo não intencionalmente, não ocorre neutralidade, portanto a pontuação zero deverá ser anotada, não possibilitando eliminar o registro em questão.

Escolhemos apresentar as ocorrências dos indicadores, já descritos e conceituados, em forma de planilha, para demonstrar em que sentido se dá estas ocorrências, o seu contexto e a sua escala agregada, no nosso caso, a Escala de Likert. A não ocorrência do indicador (0) interfere na média ponderada do indicador analisado, na medida em que sua ocorrência não agrega valores, decrescendo a média ponderada. Cabe ressaltar que a pontuação atribuída é estritamente discricional com relação à percepção de importância do evento na construção do valor agregado da cooperação.

Faremos a média a partir de cada educador (03) e cada educando (09) da LEdoC/UnB, a média entre esses segmentos, e uma média final de ocorrência de indicadores na formação do(s) valor(es) cooperativo(s). Essas ocorrências demonstradas na fala mostram o nível de consciência atual e a visão do entrevistado na construção dos valores cooperativos, em toda sua trajetória de vida, em ambientes educativos formais e informais. 
Desta forma, os resultados permitem visualizar os registros ou direcionadores de formação de consciência política de forma gráfica, bem como combinados quantitativamente. A motivação para uso desse procedimento de ponderação é o reconhecimento da existência de graus diferenciados de importância para os diversos subfatores ou sentidos, em termos de sua contribuição para o efeito agregado. Cabe aqui ressaltar que as escalas adotadas, de forma ordinal, permitem o ordenamento e classificação relativa de intensidade dos subfatores analisados, não sendo totalmente apropriado o tratamento quantitativo dos valores atribuídos. Os dados serão apresentados mediante uma média das frequências relativas das unidades de registros de cada entrevistado, e uma média final entre todos os dois segmentos de entrevistados.

As questões das entrevistas (do tipo abertas e semiestruturadas) foram colocadas de modo a permitir uma melhor percepção por parte do entrevistador, vinculando os sujeitos do processo ensino aprendizagem, docentes e discentes, a um contexto maior, possibilitando sua classificação quanto ao grau de formações de consciências políticas, enquanto processo de participação e pertencimento do indivíduo em sujeitos coletivos, e em última análise, agregação de valores cooperativos neste processo educativo.

\section{Resultados e discussões: valores agregados do segmento dos educadores}

A sistematização dos dados obtidos dos indicadores de consciência política e de formação de sujeitos coletivos dos educadores(as) entrevistados(as) (03) no caso da LEdoC/UnB, que previamente foram descritos qualitativa e quantitativamente para cada ocorrência dos indicadores analisados, onde a partir de cada sujeito pode-se gerar a tabela 01 e gráfico 01, que representa as médias agregadas dos educadores entrevistados. 
Tabela 01 - Ocorrência dos indicadores e níveis de consciência política do segmento educadores

\begin{tabular}{|c|c|c|c|c|c|c|c|c|}
\hline $\begin{array}{c}\text { Ocorrências } \\
\text { / unidades } \\
\text { de registros } \\
\text { temáticos }\end{array}$ & ic & cvs & iasa & sji & sep & vac & mac & Média \\
\hline Educador 01 & 1,71 & 1,73 & 1,56 & 1,88 & 1,86 & 1,79 & 1,85 & 1,77 \\
\hline Educadora 02 & 1,50 & 1,43 & 1,28 & 1,44 & 1,36 & 1,50 & 1,45 & 1,42 \\
\hline Educador 03 & 1,10 & 0,82 & $-0,11$ & 1,50 & 1,33 & 1,75 & 1,75 & 1,16 \\
\hline $\begin{array}{c}\text { Médias } \\
\text { Ponderadas }\end{array}$ & 1,44 & 1,33 & 0,91 & 1,60 & 1,52 & 1,68 & 1,68 & 1,45 \\
\hline
\end{tabular}

Fonte: Elaborado pelo autor

Gráfico 01 - Ocorrência dos indicadores e níveis de consciência política do segmento educadores

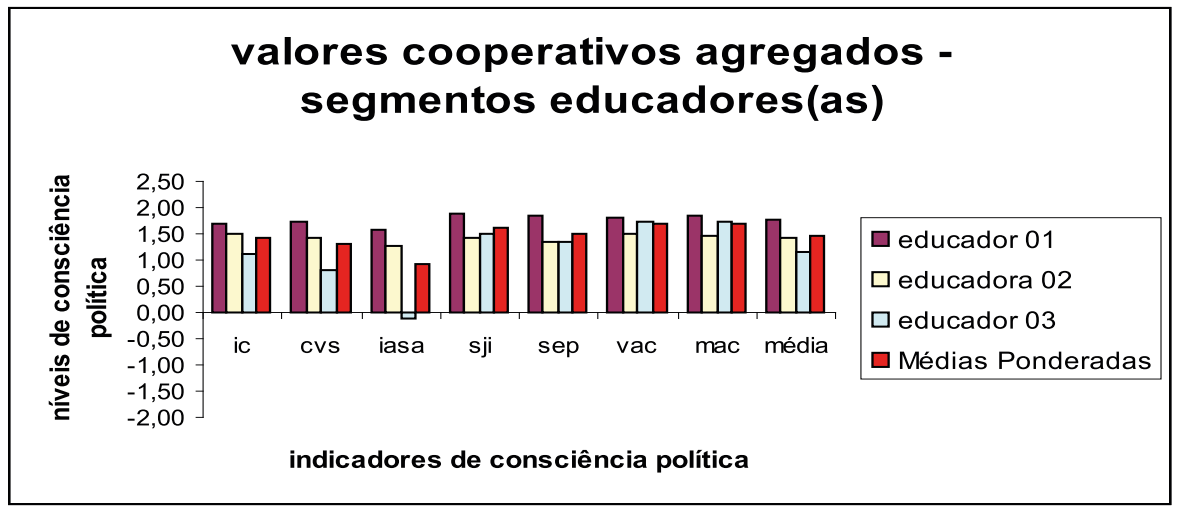

Fonte: Elaborado pelo autor

Portanto conforme evidenciado na tabela 01, temos uma média de valores cooperativos agregados do segmento dos educadores de 1,45 , própria de um nivel de consciência política práxis/política, criadora, reflexiva apropriada a um grupo que está em processo de um modelo em construção, considerado inovador e que rompe com propostas pedagógicas tradicionais. É uma prática que se volta sobre si mesma e sobre a atividade material em que se plasma, conforme os autores Sandoval (1989) e Vázquez (1990), já previamente citados na metodologia. 
Resultado dos valores agregados do segmento dos educandos (as)

Dos educados(as) entrevistados(as) (09) da LEdoC/UnB foram obtidos e sistematizados os dados dos indicadores de consciência política e de formação de sujeitos coletivos, que segue em tabela 02 e gráfico 02 , e que representa as médias agregadas.

Tabela 02 - Ocorrência dos indicadores e níveis de consciência política do segmento educandos(as)

\begin{tabular}{|c|c|c|c|c|c|c|c|c|}
\hline $\begin{array}{c}\text { Ocorrências / } \\
\text { unidades } \\
\text { de registros } \\
\text { temáticos }\end{array}$ & ic & cvs & iasa & sji & sep & vac & mac & Média \\
\hline Educando 01 & 0,36 & 1,21 & 0,88 & 1,10 & 0,50 & 0,88 & 1,00 & 0,85 \\
\hline Educando 02 & 1,75 & 1,69 & 1,35 & 1,70 & 1,28 & 1,63 & 1,75 & 1,59 \\
\hline Educando 03 & 0,58 & 0,61 & $-0,17$ & 0,58 & 0,31 & 0,71 & 0,36 & 0,43 \\
\hline Educanda 04 & 0,00 & 0,83 & 0,13 & 0,50 & $-0,33$ & 0,67 & 0,67 & 0,35 \\
\hline Educanda 05 & 1,67 & 1,36 & 1,63 & 1,67 & 1,50 & 1,50 & 1,50 & 1,55 \\
\hline Educanda 06 & 1,00 & 0,88 & 1,25 & 1,50 & 1,17 & 1,50 & 1,25 & 1,22 \\
\hline Educanda 07 & 1,17 & 0,75 & 0,25 & 1,00 & 1,00 & 1,00 & 1,00 & 0,88 \\
\hline Educanda 08 & 0,00 & 1,00 & $-1,00$ & 0,00 & $-0,63$ & $-1,25$ & $-1,25$ & $-0,45$ \\
\hline Educanda 09 & 0,50 & 1,50 & 0,50 & 0,00 & $-0,50$ & $-0,50$ & 0,00 & 0,21 \\
\hline $\begin{array}{c}\text { Médias } \\
\text { Ponderadas }\end{array}$ & 0,78 & 1,09 & 0,53 & 0,89 & 0,48 & 0,68 & 0,70 & $\mathbf{0 , 7 4}$ \\
\hline
\end{tabular}

Fonte: Elaborado pelo autor 
Gráfico 02 - Ocorrência dos indicadores e níveis de consciência política do segmento educandos(as)

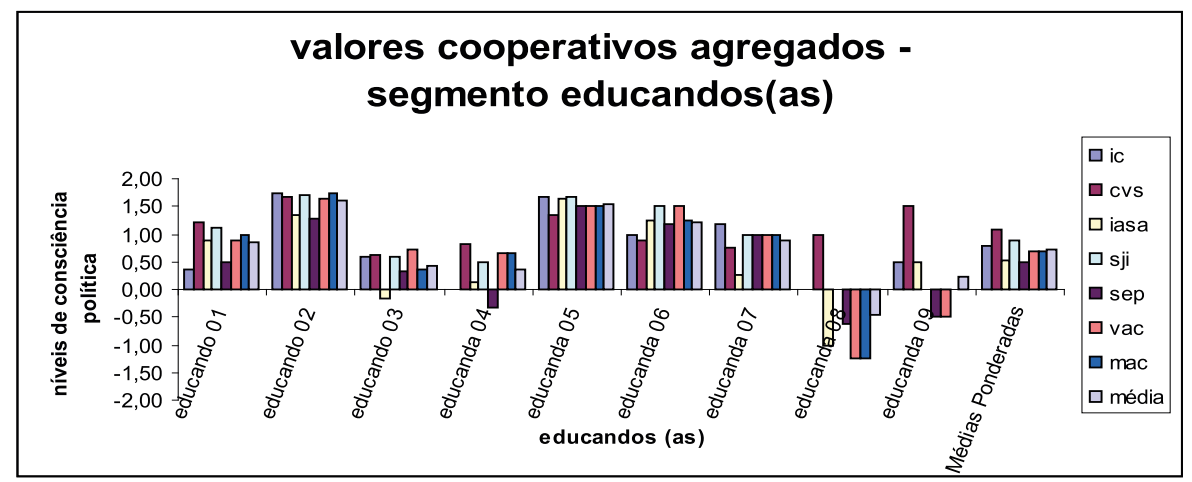

Fonte: Elaborado pelo autor

Portanto conforme evidenciado na tabela 02, temos uma média de valores cooperativos agregados do segmento dos educandos (as) de $\mathbf{0 , 7 4}$, própria de um nível intermediário entre o nível de consciência de senso comum e o nível de consciência populista, apropriada a um grupo que está em processo de formação e que, certamente, tem contado com o apoio da UnB no processo educativo, que qualifique posturas e ações que correspondam a boas avaliações individuais e coletivas, quando tratamos de inserções orientadas.

Essa faixa de nível de consciência política já rompe com o senso comum, que corresponde a uma vontade de assumir posturas cidadãs de participar nos processos de construções, buscando melhorias para a comunidade em questão, porém, conforme também evidenciado na maioria, esperam muito este suporte da universidade na intermediação dessas intervenções. Esse processo dialógico tem que intencionalmente discutir que limites e possibilidades, e de forma clara e transparente explicitar de que forma podem maximizar as atuações dos diferentes atores, bem como em que medida esse processo não possa ser dada de forma tutelada, e sim, em uma perspectiva libertária.

Resultado do diálogo e a construção dos valores cooperativos agregados entre os dois segmentos

Conforme tabela 03 e gráfico 03 , podemos concluir que a média ponderada dos valores cooperativos agregados trabalhados nesse momento na 
LEdoC, considerando os segmentos de docentes e discentes, correspondente a um valor de 1,09, que conforme metodologia escolhida se traduz em um nível de consciência política populista, onde podemos deduzir uma caracterização e uma relação de tutelamento entre os dois segmentos.

Tabela 03 - Ocorrência dos indicadores e níveis de consciência política da LEdoC.

\begin{tabular}{|c|c|c|c|c|c|c|c|c|}
\hline $\begin{array}{c}\text { Ocorrências/ } \\
\text { unidades } \\
\text { de registros } \\
\text { temáticos }\end{array}$ & ic & cvs & iasa & sji & sep & vac & mac & média \\
\hline $\begin{array}{c}\text { Médias } \\
\text { Ponderadas } \\
\text { segmento } \\
\text { docentes }\end{array}$ & 1,44 & 1,33 & 0,91 & 1,60 & 1,52 & 1,68 & 1,68 & 1,45 \\
\hline $\begin{array}{c}\text { Médias } \\
\text { Ponderadas } \\
\text { segmento } \\
\text { discentes }\end{array}$ & 0,78 & 1,09 & 0,53 & 0,89 & 0,48 & 0,68 & 0,70 & 0,74 \\
\hline $\begin{array}{c}\text { Médias } \\
\text { Ponderadas da } \\
\text { LEdoC }\end{array}$ & 1,11 & 1,21 & 0,72 & 1,25 & 1,00 & 1,18 & 1,19 & 1,09 \\
\hline
\end{tabular}

Fonte: Elaborado pelo autor

Gráfico 03 - Ocorrência dos indicadores e níveis de consciência política da LEdoC.

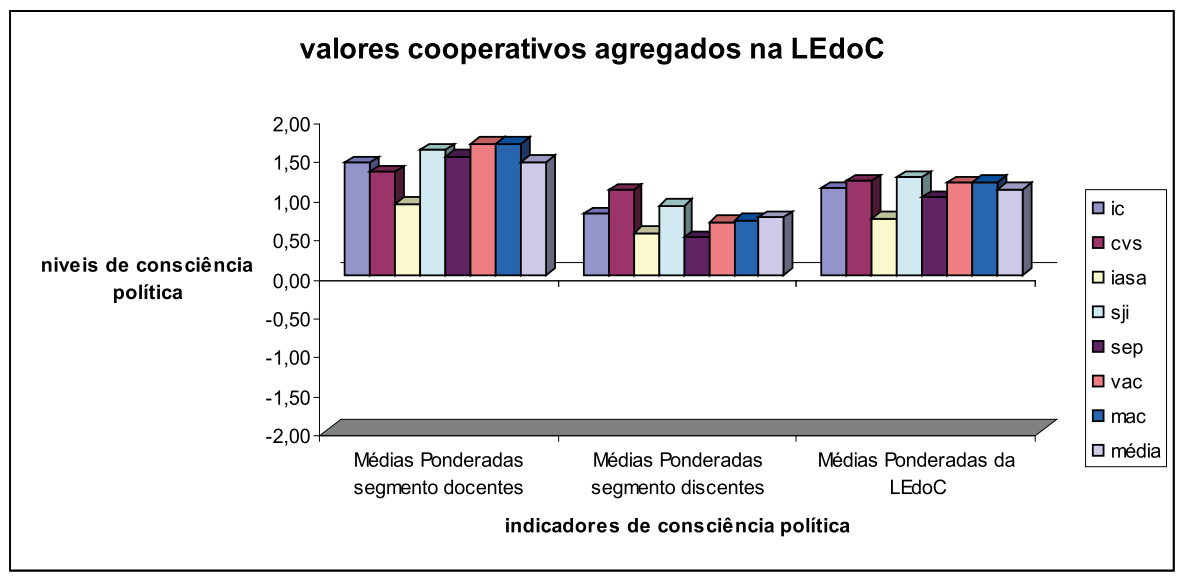

Fonte: Elaborado pelo autor

Rev. Fac. Educ. (Univ. do Estado de Mato Grosso), Vol. 28, Ano 15, № 2 p. 149-179, jul./dez. 2017 
Conforme os autores Sandoval (1989) e Vázquez (1990), esse nível de consciência política se dá em relações clientelistas, onde podemos intuir que ainda existe um caminho a percorrer para atingirmos uma educação autônoma, libertária e que cumpra os pressupostos da LEdoC em assumir uma gestão participativa, onde o segmento dos discentes se sintam com voz ativa no processo e que, nesse movimento fortaleça politicamente o coletivo, de forma a fazer diferença em suas comunidades, assumindo posturas de gestores para além da sala de aula.

Por outro lado, se considerarmos a lógica de sistema no processo educativo, teríamos um output do segmento docente de $\mathbf{1 , 4 5}$, onde esses valores impactariam o segmento discente em um processo de input, onde daí seria processado no processo tendo como resultante outro output, desta feita no segmento discente com a média de $\mathbf{1 , 0 9}$. Nesta lógica podemos intuir que o fortalecimento do coletivo dos docentes, agregando mais valores de formação de sujeitos coletivos, podendo vir a atingir um nível de consciência crítica revolucionária, certamente impactaria positivamente o segmento dos discentes, e, em última análise, potencializaria inserções orientadas a partir da participação coletiva, aproximando-se do objetivo fim da LEdoC, qual seria de transformação da realidade dos assentamentos, da melhoria da qualidade de vida dos sujeitos do campo e de um novo projeto de nação.

Conclusivamente reafirmamos a tese de que o fator aproximativo entre cooperação e colaboração, é o sentimento de pertença. A superação de um mero assistencialismo para a percepção da importância na participação em uma prática educativa e um projeto de campo que atenda suas especificidades concretas e históricas, e que promova processos autônomos e sustentáveis, requer a construção do sentimento de pertencimento a um projeto coletivo, portanto implica maiores níveis de consciência. Torna-se necessário neste processo ampliar a visão e atuação integral e coletiva por parte dos docentes, refletindo e mediando ações nas escolas e nas comunidades de inserção. Certamente este contínuo exercício impactará decisiva e positivamente a construção de consciência sobre a importância de se formar e atuar coletivamente por parte dos discentes em suas comunidades. Acreditamos este ser o foco central para fomentar e superar o nível de consciência populista apresentado pelo segmento dos discentes $(0,74)$, e que naturalmente é aceitável em um grupo que está em formação e que segue o movimento e orientação do grupo que se coloca como mediador do processo educativo. Neste movimento devem-se suplantar práticas tuteladas em uma perspectiva libertária. 
Dos tópicos que atestam a importância da metodologia adotada na LEdoC como promotora de sujeitos coletivos do campo, ressaltamos que: a indissocialidade de pesquisa, prática pedagógica e estágio no processo formativo, fomentam a produção de conhecimentos atrelados aos contextos socioculturais dos sujeitos do campo em seus exercícios baseados na práxis, intervindo em realidades; a articulação entre teoria e prática, e a vinculação entre forma e conteúdo nas práticas pedagógicas; e que em última análise traz para o processo as condições concretas da vida desses futuros educadores e de seus educandos, sujeitos do campo em luta pela garantia da manutenção desta identidade, o que impacta decisivamente na formação de identidades e de valores cooperativos desse grupo em formação, na medida em que se refletem e buscam atender necessidades comuns.

\section{Referências}

ANDRIOLI, A. I. Trabalho coletivo e educação: um estudo das práticas cooperativas do PCE - Programa de Cooperativismo nas Escolas - na região Fronteira Noroeste do Estado do Rio Grande do Sul. 2. ed. - ljuí : Ed. Unijuí, 2007. $-264 p$.

COSER, L. A. Las Funciones Del Conflicto Social. México: Fondo de Cultura Económica, 1961.

FRANCO, M. L. P. B. Análise de conteúdo. - Brasília, 2a edição: Líber Livro Editora, 2007. $80 \mathrm{p}$.

GRAMSCI, A. Concepção dialética da história. Tradução de Carlos Nelson Coutinho. 3 . ed. Rio de Janeiro: Civilização Brasileira, 1978. 341 p.

. Os intelectuais e a organização da cultura. Trad. de Carlos Nelson Coutinho. 4. ed. Rio de Janeiro: Civilização Brasileira, 1982.

MATURANA, H. Emoções e linguagem na educação e na política. Tradução de José Fernando Campos Fortes. Belo Horizonte: UFMG, 1999.

MOLINA, M. C. A Constitucionalidade e a Justicibilidade do Direito à Educação dos Povos do Campo. In: FERNANDES, B. M. (et al.); SANTOS, C. A. Por uma Educação do Campo: campo - políticas públicas - educação. Vol 7; Brasília: INCRA; MDA, 2008; 109 p. 
M. C. Transcrição da Palestra de Abertura do II ENPEC. In:MOLINA, M. C. ; MOURÃO, L. ; FREITAS, E. . II Encontro Nacional de Pesquisa em Educação do Campo e I Seminário Sobre Educação Superior e as Políticas para o Desenvolvimento do Campo Brasileiro. 2008.

PRZEWORSKI, A. Capitalismo e social-democracia. Trad. Laura Teixeira Motta. São Paulo: Companhia das Letras, 1989.

RECK, J. A Consciência política dos cooperados do MST: o caso da COOPAC Campo Verde - MT. Tese de Doutorado em Educação. UNICAMP, 2005.

SÁ, L. M. B. M. Universidade pública e relações solidárias de produção do conhecimento científico. In: Laudemair Luiz Zart et al. (Org.). Educação e Socioeconomia Solidária: Processos Organizacionais Socioeconômicos na Economia Solidária. Série Sociedade Solidária. Vol 3 (2009). Cáceres-MT: Editora Unemat, 2009. 228 p.

SANDOVAL, S. A. M. A crise Sociológica e a contribuição da Psicologia Social ao Estudo dos Movimentos Sociais. Revista Educação e Sociedade; 34; dez.1989.

. Considerações sobre Aspectos Microssociais na Análise dos Movimentos Sociais. Revista Psicologia e Sociedade; 7; Set. 1989. São Paulo: ABRAPSO.

. The crisis of the Brazilian labor movement and the emergence of alternative forms of working-class contention in the 1990s. In: Revista Psicologia Política 1 (1). São Paulo: SBPP. 2001.

. Os trabalhadores Param: Greves e Mudanças Sociais no Brasil, 1945-1990. São Paulo: Ática.

. Algumas Reflexões sobre Cidadania e Formação de Consciência Política no Brasil.In Spink, M. J. (org.) A Cidadania em Construção: Uma Reflexão Transdisciplinar. São Paulo: Cortez, 1988.

SANTOS, B. S. Um discurso sobre as ciências. São Paulo: Cortez, 2004.

SANTOS, B. S. e RODRÍGUEZ, C. Introdução: para ampliar o cânone da produção, in Produzir para viver, os caminhos da produção não capitalista, SANTOS, B. S. (org). 2a ed. Rio de Janeiro: Civilização Brasileira, 2005. 
SANTOS, C. A. Educação do campo e políticas públicas no Brasil. Dissertação (Mestrado em Educação) - Faculdade de Educação, Universidade de Brasília, 2009.

SILVA, A. S. da. Acampados no "Carlos Mariguela": um estudo sobre a formação da consciência política entre famílias do Movimento dos Trabalhadores Rurais Sem Terra no Pontal do Paranapanema - SP. São Paulo, SP, 2002. Dissertação (mestrado) - PUC- SP.

SILVA, V. P. B. V. Análise da Conformação de Qualidade da Alface Orgânica Certificada produzida no Distrito Federal.Brasília: Faculdade de Agronomia e Medicina Veterinária, Universidade de Brasília, 2005, 145 p. Dissertação de Mestrado.

SINGER, P. Uma utopia limitante. Repesando o socialismo. Petrópolis: Editora Vozes, 1998.

STAKE, R. E. The case study method in social inquiry. In DENZIN, N. K.; LINCOLN, Y. S. The American tradition in qualitative research. Vol. II. Thousand Oaks,

VAITSMAN, J. Subjetividade e paradigma de conhecimento. Boletim Técnico do Senac, v. 21, no 2, maio / agosto, 1995. Disponível em http://hospitalidade.senac.br/informativo/bts/212/2102003009.pdf. Último acesso em 27/02/2010.

VÁZQUEZ, A. S. Filosofia da Práxis.4ạ Ed. Rio de Janeiro: Ed. Paz e Terra, 1990.

VIGOTZK, V. L. S. Pensamento e linguagem. São Paulo, SP: Martins Fontes, 1993.

YIN, R. K. Estudo de caso - planejamento e métodos. (2Ed.). Porto Alegre: Bookman, 2001. 